https://doi.org/10.32689/2618-0065-2020-3(5)-87-100

Дурман Олена Леонідівна доцент кафедри державного управління i місцевого самоврядування, Херсонський національний технічний університет, кандидат наук з державного управління, 75100, Херсонська обл., м. Олешки, пров. Зоряний, 14, тел.: 0954278878, e-mail: ol.durman @ gmail.com, https://orcid.org/0000-0001-7829-9944

\title{
АНАЛІЗ ДЕЯКИХ МЕХАНІЗМІВ ДЕРЖАВНОГО УПРАВЛІННЯ ДЛЯ ФОРМУВАННЯ ЗОВНІШНЬОЇ ПОЛІТИКИ
}

Анотація. В статті здійснюється аналіз механізмів державного управління формування зовнішньої політики держави на основі синтезу сучасних досліджень та системного підходу.

Досліджується, що розвиток зовнішніх функцій держави супроводжується динамічною зміною, тобто відбувається еволюційний розвиток структури зовнішніх функцій, еволюція зовнішньополітичного механізму.

Описується поділ органів зовнішніх зносин на дві групи: внутрішньодержавні (центральні) та закордонні. а повсякденну оперативну діяльність, пов'язану із зовнішніми зносинами держави, в першу чергу, здійснює спеціально уповноважений орган виконавчої влади, який курує сферу міжнародних відносин - Міністерство закордонних справ України.

Вказується, що успішна реалізація Україною своїх зовнішньополітичних можливостей залежить, в першу чергу, від комплексу конституційноправових, організаційних та дипломатичних заходів що здійснюються суб'єктами державного управління у сфері зовнішньополітичній діяльності України, які об'єднуються у політико-дипломатичний механізм у сучасній зовнішньополітичній діяльності України.

Проте, якими б не були механізми формування зовнішньої політики, різко змінити зовнішньополітичний курс держави рішеннями певних осіб чи органів практично неможливо - цьому буде перешкоджати самі ці механізми (які). Це буде відбуватися з різних причин, але нам цікаво дослідити це 3 точки зору поєднання системного підходу i такого поняття як «лійка причинності».

Проаналізовано, що проблеми зовнішньої політики держави мають складний, комплексний характер, і це вимагає більш скоординованої і єдиної співпраці окремих організаційних структур, які і являють собою механізми зовнішньої політики держави, які будуть нести за вирішення зовнішніх проблем всю повноту відповідальності. Місце та роль уряду в механізмі здійснення зовнішньої політики залежить насамперед від форми правління в державі й політичної системи суспільства. 
Узагальнено, що використання нових підходів до аналізу процесів формування зовнішньополітичного курсу країни на основі системного підходу та методів, що застосовуються у суспільних науках, дає можливість поглянути на ці процеси 3 нового боку і отримати нове бачення механізмів державного управління, що використовуються у цих процесах.

Ключові слова: механізми державного управління, зовнішня політика, зовнішні зносини, зовнішньополітичний курс, Міністерство закордонних справ.

Durman Olena Leonidovna Associate Professor, Department of Public Administration and Local Self-Government, Kherson National Technical University, $\mathrm{PhD}$ in Public Administration, 75100, Kherson region, Oleshki, prov. Star, 14, tel: 0954278878, e-mail: ol.durman@gmail.com, https//orcid.org/00000001-7829-9944

\section{ANALYSIS OF SOME MECHANISMS OF PUBLIC GOVERNANCE FOR FORMATION OF FOREIGN POLICY}

Abstract. The article analyzes the mechanisms of government for the formation of the state's foreign policy based on a synthesis of modern research and a systematic approach.

It is investigated that the development of the external functions of the state is accompanied by a dynamic change, that is, there is an evolutionary development of the structure of external functions, the evolution of the foreign policy mechanism.

The division of foreign relations bodies into two groups is described: domestic (central) and foreign, but the daily operational activities related to the state's foreign relations are, of course, primarily carried out by a specially authorized executive body that oversees the sphere of international relations - the Ministry of Foreign Affairs of Ukraine .

It is indicated that the successful implementation of Ukraine's foreign policy opportunities depends, first of all, on the complex of constitutional, legal, organizational and diplomatic measures undertaken by public administration entities in the field of Ukraine's foreign policy activities are combined into a political and diplomatic mechanism in Ukraine's modern foreign policy activity.

However, no matter what the mechanisms of the formation of foreign policy may be, it is practically impossible to drastically change the state's foreign policy by decisions of certain individuals or bodies - these mechanisms themselves will impede this. This will happen for various reasons, but we are interested in exploring this from the point of view of combining a systematic approach and such a thing as a "funnel of causality".

It is analyzed that the problems of the state's foreign policy are complex, integrated, and this requires more coordinated and unified cooperation of individual organizational structures, and they are the mechanisms of the state's foreign policy, will be responsible for solving external problems all the 
responsibility. The place and role of government in the mechanism of foreign policy implementation depends primarily on the form of government in the state and the political system of society.

The review that the use of new approaches to the analysis of the processes of formation of the country's foreign policy based on the systematic approach and the methods used in the social sciences makes it possible to look at these processes from a new perspective and gain a new vision of the mechanisms of government used in these processes.

Keywords: governance mechanisms, foreign policy, foreign relations, foreign policy, Ministry of Foreign Affairs

Постановка проблеми. Досліджуючи хід історії розвитку зовнішньої політики української держави та становлення іiї зовнішньополітичних структур [1], можна спостерігати глобальні зрушення та позитивну тенденцію щодо розвитку зовнішньополітичних зв'язків, переорієнтації української держави на засади цінностей західної демократії та серйозної участі у світовій політиці. За роки незалежності Україна набула значного досвіду формування зовнішньополітичного курсу. В той же час залишається проблемою формування дієвих механізмів забезпечення суб'єктності зовнішньополітичного курсу України.

Аналіз останніх досліджень і публікацій. Питання змісту зовнішньої політики, механізмів iї функціонування i реалізації $\epsilon$ надзвичайно актуальними питаннями у сучасній науці. Якісні дослідження реального зовнішньополітичного процесу містяться у працях таких зарубіжних вчених як: Г. Аллісона, М. Брешера, М. Хелперіна, І. Дестлера, А. Джорджа, С. Хантінгтона, Р. Хілсмана, О. Холсті, К. Уолтца й багатьох інших. Щодо вітчизняних вчених, які зробили вклад у вивчення та становлення основних принципів і концептуальних засад зовнішньої політики нашої держави, то цим питанням присвятили праці Ю. Макар [2], О. Макаренко [3], К. Сандровський [4], Ю. Тодика [5], В. Погорілко [6] та інші.

Широке коло досліджень механізмів державної політики, 3 одного боку, створює можливості для глибокого розуміння змісту, процесів, механізмів, інструментів всіх політичних процесів держави. Проте, з іншого боку, досліджень саме щодо механізмів зовнішньої політики, у межах цього широкого кола, дуже мало. Це певним чином ускладнює процес пізнання окремих аспектів формування зовнішньої політики, тому що процеси, які сьогодні мають місце у сфері міжнародних відносин, характеризуються значним розмаїттям та складністю. Причиною цього є глобалізація та регіоналізація міжнародних відносин, що вимагає від держав перегляду старих способів взаємодії, вдосконалення механізмів співпраці, розробки зовнішньої політики, адекватної сучасним обставинам.

Метою статті $\epsilon$ аналіз механізмів державного управління для формування зовнішньої політики держави на основі синтезу сучасних досліджень та системного підходу. 
Виклад основного матеріалу. Розвиток зовнішніх функцій держави супроводжується динамічною зміною (розширенням, звуженням, зміною функціональності) механізмів державного управління, якими керуються державні органи відповідальні за здійснення зовнішньої політики. Фактично відбувається еволюційний розвиток структури зовнішніх функцій, еволюція зовнішньополітичного механізму.

Що стосується органів державної влади, які наділені спеціальною компетенцією у сфері зовнішніх зносин, то вони діють від імені держави, виступають представниками суверенної влади держави за кордоном.

Вітчизняний юрист-міжнародник К. К. Сандровський запропонував таке визначення державних органів зовнішніх зносин: «...це діючі на території держави та поза ï межами спеціальні органи, які представляють державу в іï офіційних відносинах 3 іншими державами та суб'єктами міжнародного права і забезпечують виконання зовнішньополітичних цілей мирними, передбаченими міжнародним правом засобами, з метою захисту прав та інтересів даної держави, а також пї організацій та громадян, що знаходяться за кордоном» $[4, \mathrm{c.}]$.

Вчені В. А. Зорін та К. К. Сандровський поділяють органи зовнішніх зносин на дві групи: внутрішньодержавні (центральні) та закордонні. В свою чергу, перша група органів зовнішніх зносин держави поділяється за характером своїх функцій та правового обгрунтування на органи загальнополітичного керівництва, чий статус визначається, як правило, конституціями держав та органи спеціальних (галузевих, відомчих) зносин держави з іншими країнами [7] (рис.1).

Закордонні органи поділяються також на два типи - постійні та тимчасові. Тому, розглядаючи питання, пов'язані 3 функціонуванням відповідних державних органів, автор вважає доречним врахувати думку фахівців-міжнародників, які класифікували їх, насамперед, із точки зору їх розташування. Такий поділ видається нам універсальним i, попри все розмаїття сучасних політичних та економічних систем, може бути застосованим до будь-якої країни світу. При цьому слід зауважити, що держава сама визначає, в якому порядку і за допомогою яких власних органів ій належить виконувати свої зовнішні функції. 


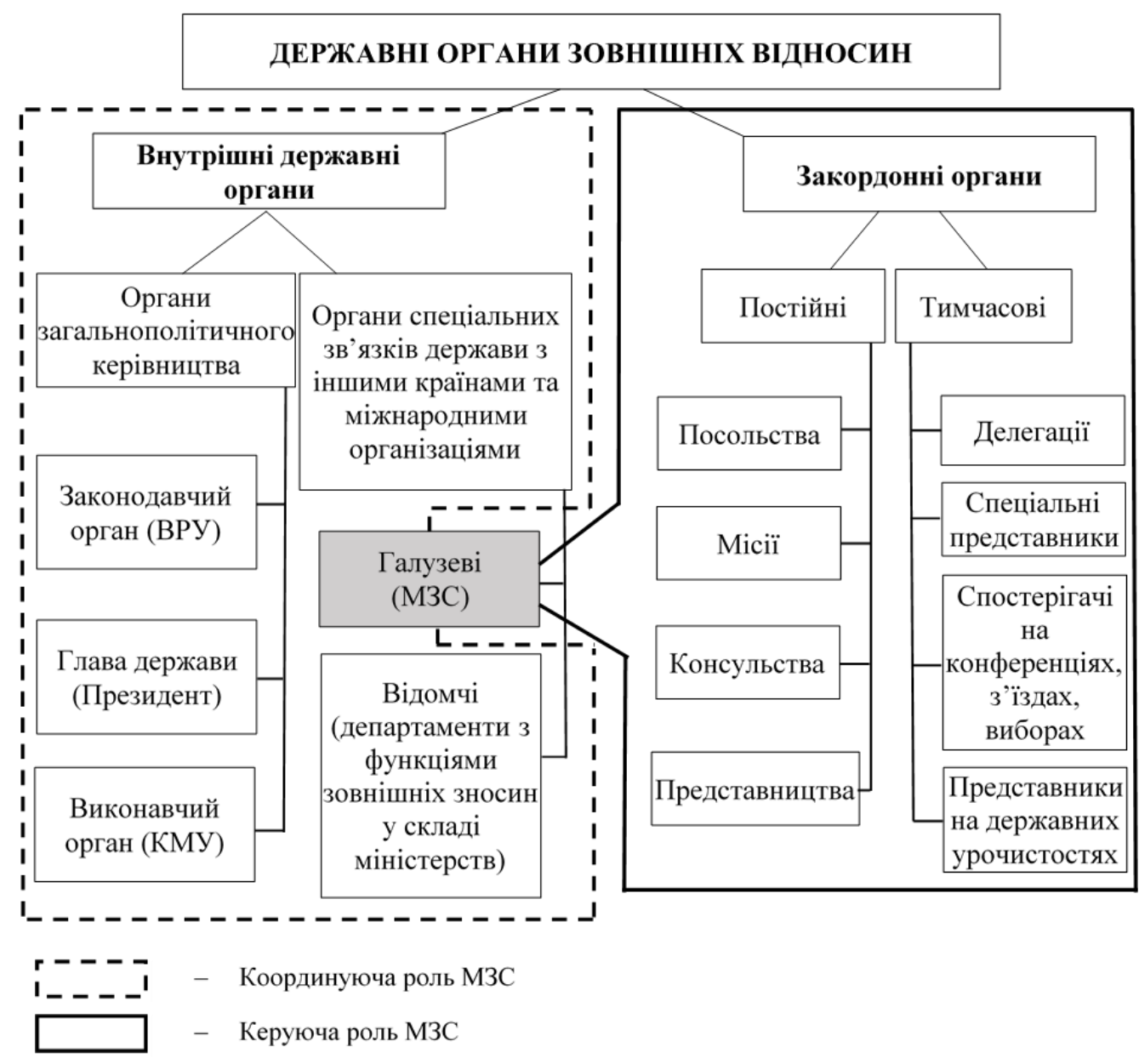

Рис. 1. Органи зовнішніх відносин

Повсякденну оперативну діяльність, пов'язану із зовнішніми зносинами держави, в першу чергу, здійснює спеціально уповноважений орган виконавчої влади, який курує сферу міжнародних відносин Міністерство закордонних справ України. Воно є основною найважливішою ланкою здійснення конституційно-правового механізму організації реалізації державної політики у сфері зовнішніх зносин та координації зовнішньополітичної діяльності різних міністерств і відповідних заходів, що спрямовані на досягнення стратегічних цілей зовнішньої політики України, зокрема, забезпечення входження України в європейський простір.

Відповідно до п. 3 Положення про Міністерство закордонних справ України, затвердженого постановою Кабінету Міністрів України від 6 квітня 2011 року [8], МЗС забезпечує проведення зовнішньополітичного курсу України, спрямованого на розвиток політичних, економічних, гуманітарних, наукових, інших зв'язків 3 іноземними державами та міжнародними організаціями.

Міністерство здійснює свої повноваження безпосередньо та через дипломатичні представництва за кордоном, а також представництва МЗС України на території України. Що стосується закордонних державних органів зовнішніх зносин, то вони поділяються на дві головні категорії - постійні та 
тимчасові. Постійні органи ведуть повсякденну роботу за кордоном, представляючи і захищаючи національні інтереси своєї держави. Йдеться про посольства, консульства, представництва України у міжнародних організаціях. Тимчасові органи - це спеціальні місії, різноманітні делегації, окремі представники за кордоном, а також спостерігачі на міжнародних конференціях, з’іздах, у міжнародних комісіях тощо.

Провідне місце у конституційно-правовому механізмі реалізації зовнішніх зносин займають центральні органи виконавчої влади, які в законодавчому порядку наділені повноваженнями у сфері здійснення зносин 3 іноземними державами та міжнародними організаціями. Як зазначає швейцарський дослідник Ф. Брайар, зовнішня політика усе в меншій мірі $€$ долею тільки міністерства закордонних справ. У силу зростаючої необхідності спільно керувати все більш складними i численними проблемами, вона стає справою більшості інших державних відомств та структур [9].

Конституційно-правовий механізм реалізації зовнішніх зносин являє собою складну та багаторівневу, розгалужену систему діяльності залежних один від одного функціонально органів державної влади та посадових осіб, зовнішньополітична компетенція яких регламентована Конституцією України та сукупністю інших взаємопов'язаних нормативно-правових актів 3 приводу здійснення зовнішньої функції держави. У зв’язку 3 цим, даний механізм держави має розглядатися не як набір його складових, а як система функціонально сумісних та узгоджених між собою складових, які перебувають у постійному відновленні з метою підтримання своєї основної функції - управління зовнішніми відносинами.

Сучасна конституційно-правова доктрина розглядає конституційноправовий механізм реалізації зовнішніх зносин в декількох аспектах. Так, М. О. Баймуратов зазначає, що механізм конституційно-правового забезпечення зовнішньополітичної діяльності України складається 3 нормативного, організаційного та організаційно-правового блоків [10].

В свою чергу О. Г. Макаренко умовно поділяє його на дві складові частини: організаційно-правову (інституційну) - систему діяльності взаємопов'язаних та функціонально залежних органів державної влади та посадових осіб, наділених компетенцією та повноваженнями для здійснення зовнішньополітичної функції держави та нормативно-правову - сукупність нормативно-правових актів, до яких належать: конституційні положення та норми загального характеру, які характеризують конституційно-правову сутність зазначеного механізму; спеціальні норми, які уповноважують державні органи влади вживати заходи і засоби для здійснення ними своїх зовнішньополітичних повноважень, а також норми, що визначають функціональні взаємозв' язки між ними [3].

Науковець Е. Я. Павлов виділяє три складових конституційноправового механізму реалізації зовнішніх зносин: організаційну, правову та функціональну [11]. 
Успішна реалізація Україною своїх зовнішньополітичних можливостей залежить, в першу чергу, від організаційного механізму реалізації зовнішних зносин. Долаючи кризові явища в суспільстві і прокладаючи свій шлях у світі, Україна спирається на свої фундаментальні загальнонаціональні інтереси. Відповідно до таких інтересів і визначаються засади, напрями, пріоритети та функції ії зовнішньої політики.

Організаційні заходи в рамках організаційного механізму здійснюються суб'єктами державного управління у сфері зовнішньополітичній діяльності України і спрямовані на забезпечення єдиної координації та взаємодії між Президентом України, Верховною Радою України та Урядом (Кабінетом Міністрів України, Міністерством закордонних справ України). Проведення зовнішньої політики України, координація діяльності міністерств, інших органів виконавчої влади у сфері зовнішніх зносин покладається на Міністерство закордонних справ України.

Міністерства та інші центральні органи виконавчої влади, закордонні дипломатичні органи, Служба безпеки України та Служба зовнішньої розвідки України та інші, які входять до складу організаційного елементу одночасно є представниками конституційно-правового механізму реалізації зовнішньої політики і в межах своїх повноважень забезпечують виконання передбачених Конституцією та законами України, нормативно-правовими актами Президента України та Кабінету Міністрів України завдань у сфері зовнішніх зносин держави.

Чітке усвідомлення національних інтересів України надзвичайно важливе для проведення послідовної та цілеспрямованої політики у відносинах із іншими країнами, а також для вироблення стратегії розвитку своєї державності. Структура конституційно-правового механізму реалізації зовнішньої політики відображає сформовану в державі загальну систему й ієрархію органів державної влади і посадових осіб, їх співвідношення і підпорядкованості, наділених своєю компетенцією та повноваженнями, яка відповідає їх місцю у даній системі і узгоджена 3 компетенцією інших органів.

Конституційно-правові заходи здійснюються суб'єктами державного управління у сфері зовнішньополітичній діяльності України та спрямовані на удосконалення національної законодавчої бази в обсязі, необхідному для ефективного забезпечення національних інтересів і безпеки шляхом підтримання мирного i взаємовигідного співробітництва на основі загальновизнаних принципів і норм міжнародного права.

У свою чергу дипломатичні заходи здійснюються Міністерством закордонних справ України у відповідності до генеральних директив, схвалених Президентом України. Ці заходи передбачають:

прискорення процесу європейської та євроатлантичної інтеграції України;

залучення широкої міжнародної підтримки світової спільноти прагненням України захистити суверенітет та територіальну цілісність; 
забезпечення повноправної участі України у міжнародних та регіональних безпекових структурах;

розвиток міжнародного співробітництва та співпраці 3 провідними країнами світу;

імплементацію міжнародних проектів і програм у сфері зовнішніх зносин тощо.

На сьогодні основну законодавчу базу зовнішньої політики складають наступні документи: Конституція України [12], Закон України «Про засади внутрішньої і зовнішньої політики України» [13], Закон України «Про дипломатичну службу» [14] та Стратегія національної безпеки України [15, перевірити мабуть пізніше].

3 погляду функціонального змісту зовнішньополітична діяльність держави покликана забезпечити вирішення низки взаємозалежних завдань:

1. Забезпечення безпеки держави на міжнародній арені у процесі іiі взаємодії з іншими країнами, формування та підтримання функціонування системи міждержавних відносин на двосторонньому, регіональному й глобальному рівні.

У зв’язку із цим випливає й інше завдання, а саме - сприяння процесу формування такої системи міжнародних відносин, що у максимальному ступені сприяє інтересам національної безпеки країни.

2. Реалізація національно-державних інтересів на міжнародній арені, створення сприятливих міжнародних умов для соціальноекономічного, політичного й культурного розвитку країни.

3. Поширення й впровадження у практику міжнародних відносин системи цінностей та ідеалів, що лежать в основі політичної системи суспільства.

4. Корекція зовнішньополітичної стратегії, зовнішньополітичного курсу держави відповідно до мінливих умов міжнародних відносин.

Отже, комплекс конституційно-правових, організаційних та дипломатичних заходів що здійснюються суб'єктами державного управління у сфері зовнішньополітичній діяльності України об'єднуються у політикодипломатичний механізм сучасної зовнішньополітичної діяльності України.

Ще один варіант розуміння зовнішньої політики - інституціональний, пов’язаний із процесом реалізації рішень. Мова ведеться про урядові механізми зовнішньої політики (foreign affairs government structure), під якими розуміються діяльність державних інституцій, які відповідальні за формування й здійснення зовнішньої політики. У кожній країні подібні механізми мають свої особливості.

Проте, якими б не були механізми формування зовнішньої політики, різко змінити зовнішньополітичний курс держави рішеннями певних осіб чи органів практично неможливо - цьому буде перешкоджати самі ці механізми. Це буде відбуватися з різних причин, але нам цікаво дослідити це з точки зору поєднання системного підходу і такого поняття як «лійка причинності».

«Лійка причинності» - поняття, введене американським дослідником Дж. Розенау [16] і детальніше розроблене американськими політологами Ч. 
Кеглі-Мол і Ю. Уіткопфопом [17]. Вони ії використовують для пояснення формування того чи іншого рішення певними суб'єктами в соціології (вибори, референдуми, інші види голосування). На думку цих вчених, вся інформація й імпульси всіх впливів, так чи інакше позначаються на зовнішній політиці та групуються по лініях п'яти «джерел», розташованих у широкій частині «лійки» і відкривають вхід у глибини політичного організму країни. Ми ж спробуємо застосувати цю «лійку» до формування зовнішньої політики держави.

В роботах вищезгаданих авторів порядок впливів - стандартний і не може бути змінений. Ми ж запропонуємо наступні групи факторів внутрішнього державного середовища, що впливають на формування зовнішнього курсу держави (див. рис. 2):

політичні фактори;

ідеологічні фактори (зовнішньополітична пропаганда);

економічні фактори;

воєнні фактори;

соціальні фактори.

Кількість груп факторів може бути величиною змінною, a їx розміщення- довільним. В залежності від ситуації в країні та за ії межами, лідерів та громадськості, на перші місця можуть виступати різні фактори. Так, в складних економічних умовах - економічні, в період соціальних збурень - соціальні, під час воєнних конфліктів - воєнні тощо.

Фактично, внутрішні фактори можна розглядати як певні «сита», проходячи через які альтернативи тих чи інших управлінських рішень, що формують зовнішню політику держави, відсікаються або трансформуються. Застосування саме такого підходу, з одного боку, показує можливі напрямки зовнішньої політики, а з іншого - дає можливість отримати варіативність рішень в залежності від того, які фактори («сита») будуть враховуватися як першочергові. 


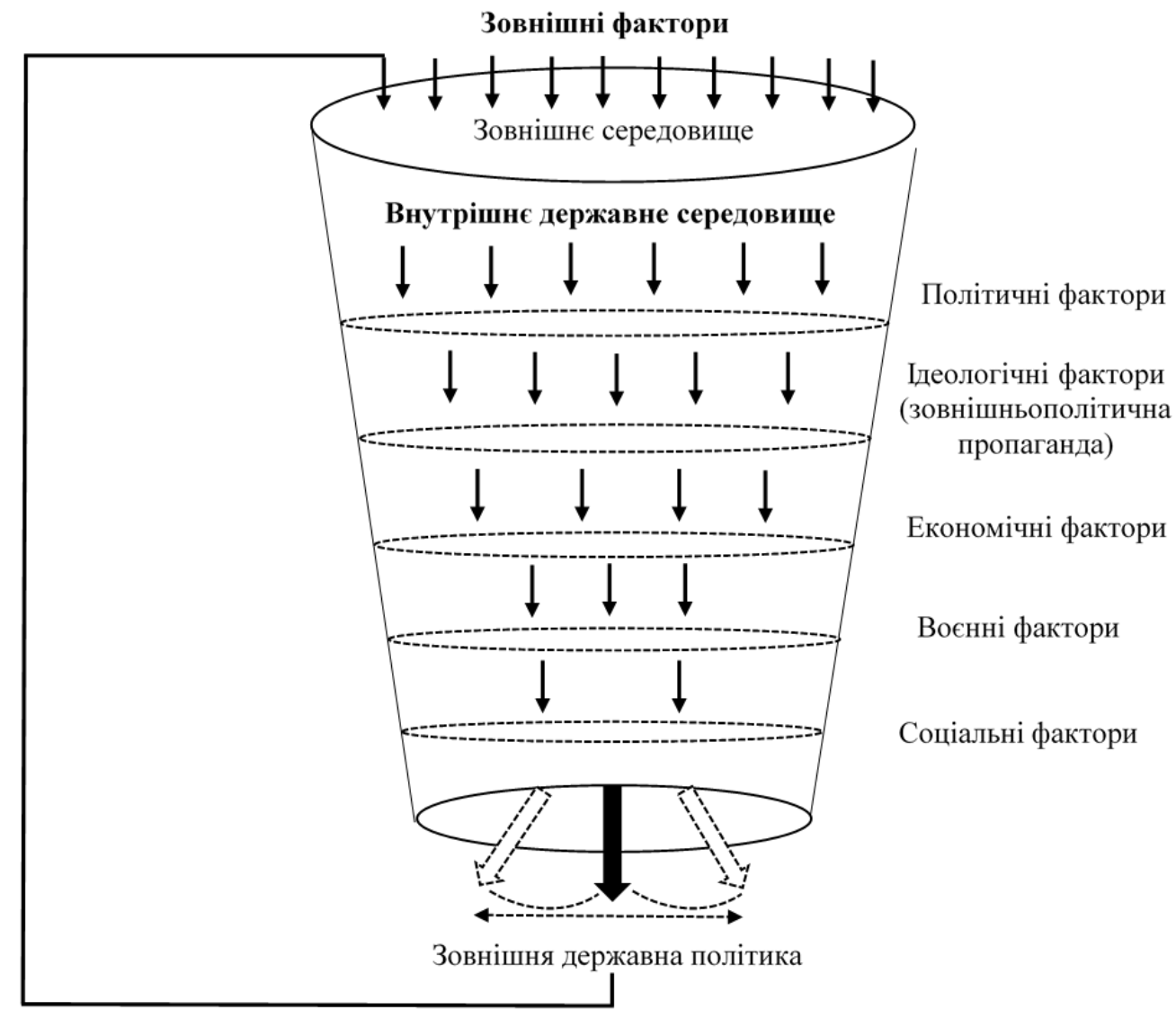

Рис. 2. «Лійка причинності» відносно до формування зовнішнього курсу країни.

Потік альтернативних управлінських рішень падає углиб «лійки», іiі стінки визначають обмеження на ухвалення рішень, у тому числі й часові. Контури зовнішньої політики визначаються «на виході», у вузькій частині лійки.

При такому описі процесу широкий спектр початкових альтернативних рішень відсіюється в обмежений набір вихідних альтернатив. Надлишкова інформація й слабко виражені впливи відфільтровуються «ситами», а результуюча політика, що з'являється на виході, сполучає у собі стабільність та спадкоємність курсу, але одночасно й ті зміни, які були підготовлені набором зовнішніх та внутрішніх впливів та «сит».

При цьому зовнішня політика, яку ми отримуємо в результаті, виступає також вхідним параметром зовнішнього середовища і враховується на наступній ітерації формування зовнішнього курсу. Таким чином, неможливо одномоментно змінити курс зовнішньої політики на $180^{\circ}$, проте в довогостроковій перспективі, за рахунок маленьких флуктацій «витоку лійки», ми можемо отримати можливість зміни зовнішньополітичного курсу.

3 іншого боку, оскільки зовнішня політика асоціюється 3 рішеннями тих, хто діє від імені держави, тобто офіційних осіб, то саме дія виступає 
центральним компонентом політики. Наявність такої «лійки причинності» унеможливлює суттєве погіршення міждержавних відносин за рахунок одного, негативного, для цих відносин рішення будь-якого високопосадовця. Таку ситуацію ми можемо спостерігати, наприклад, в США, де імпульсивні рішення Президента Д. Трампа, проходячи через «лійку причинності», згладжуються іншими рішеннями владних інституцій. При цьому загальний зовнішньополітичний курс держави зберігається.

Ресурси, використовувані в зовнішній політиці державою (політикодипломатичні, економічні, військові, правові, інформаційні й т.і.), перебувають у iii окремих структурноорганізаційних підрозділах (МЗС, Міністерства оборони, Міністерства фінансів і т.д.). Коли вища влада обирає які-небудь альтернативні засоби досягнення зовнішньополітичних цілей, вона спирається на організаційні можливості відповідних структур державного апарату.

Необхідно відзначити, що для будь-якої держави характерна певна інтегрованість у систему міжнародних відносин, що робить свій вплив на внутрішньополітичні процеси, а тим більше на зовнішньополітичні.

Відповідно до стану свого розвитку кожна держава відчуває на собі еволюцію системи міжнародних відносин, сутність якої складається в усе зростаючому впливі зовнішнього світу на економічні, політичні, соціальні й інші процеси усередині країни, i тому змушена будувати політику 3 урахуванням сформованих зв'язків системи міжнародних відносин і змін, що відбуваються в ній, про що свідчить «лійка причинності», схема якої запропонована вище.

Безпосередньою передумовою, імпульсом, що спонукає суб'єкта політики до діяльності, виступає усвідомлення й осмислення ним змін, які відбуваються у країні й світі, що проявляється як інтерес. Однак сам по собі інтерес залишається нереалізованим доти, поки не буде сформована політичним керівництвом країни мета, прийняте політичне рішення, що визначає шляхи й засоби ії досягнення (фактично, набір та порядок «сит», що використовуються для формування зовнішнього курс країни). Таким чином, політичний курс держави для того, щоб стати політичною реальністю, повинен базуватися на усвідомленні необхідності змін політики правлячою елітою або ії політичним керівництвом, на певному політичному рішенні, що випливає 3 національнодержавних інтересів. Дане рішення може бути прийняте й оформлене законодавчо або будь-яким іншим способом, що припускає політична організація суспільства.

I в інших країнах, і в Україні механізми такого роду мають значний «ресурс опору». Це означає, що реалізація одних програм може бути істотно вповільнена, блокована, реалізація інших - прискорена або просто нав'язана [18]. Але як би то не було, інституціональний механізм - основний інструмент реалізації зовнішньополітичних рішень, і успіх зовнішньої політики залежить у величезному ступені від нього. Фактично зовнішня політика виробляється в рамках подібних механізмів. 
Існування системи зовнішньополітичних (міжнародних) відносин на всіляких рівнях викликає необхідність формування деякої кількості зовнішньополітичних цілей стратегічного й тактичного порядку, що перебувають між собою в тісному зв'язку координації й субординації.

Формування або «інжиніринг» зовнішньої політики, на думку американського вченого Ф. Зелікова, будується на основі семи складових: національних інтересах, цілях, стратегії, дизайні (переведення стратегії до оперативних планів, які визначають, що повинне відбутися в реальному світі), реалізації, повсякденному здійсненні й перегляді [18].

Цікаво, що стадія реалізації політики в такій схемі розпадається на три фази: «запуск» нової політики, її послідовне («підтримуюче») проведення й перегляд, модифікація курсу. Стратегія виявляється теорією, що описує відношення між діями уряду й поводженням інших гравців. Мова ведеться про «теорію переконання», що сприяє досягненню результату. Реалізація політики не може початися раніше, ніж погоджений дизайн.

Висновки та перспективи подальших досліджень. Аналіз наведених міркувань дозволяє зробити висновок про те, що проблеми зовнішньої політики держави мають складний, комплексний характер, i це вимагає більш скоординованої i єдиної співпраці окремих організаційних структур, діяльність яких і являє собою механізм зовнішньої політики держави. Місце та роль уряду в механізмі здійснення зовнішньої політики залежить насамперед від форми правління в державі й політичної системи суспільства.

Використання нових підходів до аналізу процесів формування зовнішньополітичного курсу країни на основі системного підходу та методів, що застосовуються у суспільних науках, дає можливість поглянути на ці процеси 3 нового боку і отримати нове бачення механізмів державного управління, що використовуються у цих процесах.

Наступні наукові розвідки ми вбачаємо в застосуванні системного підходу до аналізу варіативності рішень, на яких грунтується формування зовнішньополітичного курсу країни.

\section{Jimepamypa:}

1. Дурман О. Л. Розвиток зовнішньої політики та становлення зовнішньополітичних структур України: історичний аспект. Держава та регіони: науково-виробничий журнал. Серія: Державне управління. Запоріжжя. 2019. № 4 (68). С. 22-30.

2.Макар Ю. Зовнішня політика України: наміри і реалії. Україна-Свропа-Світ. Міжнародний збірник наукових пращь. Серія: Історія, міжнародні відносини. Вип.1 Тернопіль: Вид-во ТНПУ ім. В. Гнатюка. 2008. С. 189-198.

3. Макаренко О. Г. Конституційно-правовий механізм здійснення зовнішніх зносин України: автореф. дис. ... канд. юрид. наук: 12.00.02. Ін-т законодавства ВРУ. Київ, 2009. $20 \mathrm{c}$.

4. Сандровский К. К. Право внешних сношений. Київ: Вища школа.1986. 328 с.

5. Тодика Ю. М. Конституційне право України. Підруч. Київ: Ін Юре. 2002. 544 с.

6. Погорілко В. Ф. Конституційне право України. Київ: Правова єдність. 2010. 432 с.

7. Зорин В. А. Основы дипломатической службы. Москва: Межд. отношения. 1977. $368 \mathrm{c}$. 
8. Про затвердження Положення про Міністерство закордонних справ України: постанова Кабінету Міністрів України від 30 березня 2016 р. № 281. // База даних «Законодавство України». / ВP України. URL: https://zakon.rada.gov.ua/laws/show/2812016-\%D0\%BF\#Text (дата звернення: 20.05.2020).

9. Braillard $\mathrm{Ph}$. Relations internationales: une nouvelle discipline. Le trimestre du monde. 1994. № 3. P. 29.

10. Баймуратов М. О. Теоретичні аспекти конституційно-правового забезпечення зовнішньополітичної діяльності держави в умовах глобалізації та європейської інтеграції. Вісник Маріупольського державного університету : Збірник наукових праць. Серія: Право. 2014. Вип. 7. С. 10-27.

11. Павлов Е. Я. Конституционно-правовой механизм осуществления внешних сношений РФ (теоретические основы). Вестник МГИМО-Университета. 2012. № 2. С. 156-162.

12. Конституція України: Головний Закон України від 28 червня 1996 року. // База даних «Законодавство України». / BP України.URL: https://zakon.rada.gov.ua/laws/show/254\%D0\%BA/96-\%D0\%B2\%D1\%80 (дата звернення: 20.05.2020).

13. Про засади внутрішньої і зовнішньої політики України: Закон України від 1 липня 2010 року № 2411-VI. // База даних «Законодавство України». / BP України. URL: https://zakon.rada.gov.ua/laws/show/2411-17 (дата звернення: 20.05.2020).

14. Про дипломатичну службу: Закон України від 7 червня 2018 року № 2449-VIII. // База даних «Законодавство України». / BP України. URL: https://zakon.rada.gov.ua/laws/show/2449-19 (дата звернення: 20.05.2020).

15. Про Стратегію національної безпеки України: рішення Ради Національної Безпеки і Оборони України від 6 травня 2015 року. // База даних «Законодавство України». / ВР України. URL: https://zakon.rada.gov.ua/laws/show/n0008525-15 (дата звернення: 20.05.2020).

16. J. Rosenau. Turbulence in World Politics: A Theory of Change and Continuity. Princeton: Princeton University Press, 1990. 480 p.

17. Kegley C. W. Jr., Wittkopf E.R. American Foreign Policy: Pattern and Process. 5th Edition. New York: St. Martin's Press, 2001. 658 p.

18. D.W. Dregner. Ideas, Bureaucratic Politics and the Crafting of Foreign Policy. American Journal of Political Science. October 2000. Vol. 44. № 4. P. 733-749.

19. Ph. Zelikow. Foreign Policy Engineering: From Theory to Practice and Back Again. International Security. Spring 1994. Vol. 18. №. 4. P. 143-171.

\section{References:}

1. Durman, O.L. (2019). Rozvytok zovnishnoi polityky ta stanovlennia zovnishnopolitychnykh struktur Ukrainy: istorychnyi aspekt [Development of foreign policy and formation of foreign policy structures of Ukraine: historical aspect]. Derzhava ta rehiony: naukovo-vyrobnychyi zhurnal. Seriia: Derzhavne upravlinnia - Countries and regions: a scientific and production journal. Series: Public Administration, 4(68), 22-30 [in Ukrainian].

2. Makar, Yu. (2008). Zovnishnia polityka Ukrainy: namiry i realii. Ukraina-Yevropa-Svit [Foreign Policy of Ukraine: Intentions and Realities. Ukraine-Europe-World]. Mizhnarodnyi zbirnyk naukovykh prats. Seriia: Istoriia, mizhnarodni vidnosyny - International Collection of Scientific Papers. Series: History, International Relations, 1, 189-198 [in Ukrainian].

3. Makarenko, O.H. (2009). Konstytutsiino-pravovyi mekhanizm zdiisnennia zovnishnikh znosyn Ukrainy [Constitutional-legal mechanism of realization of external relations of Ukraine]. Extended abstract of candidate's thesis. Kyiv: In-t zakonodavstva VRU [in Ukrainian].

4. Sandrovskiy, K.K. (1986). Pravo vneshnykh snoshenyi [The right of external relations]. Kyiv: Vyshcha shkola [in Russian].

5. Todyka, Yu.M. (2002). Konstytutsiine pravo Ukrainy [Constitutional Law of Ukraine]. Kyiv: In Yure [in Ukrainian]. 
6. Pohorilko, V.F. (2010). Konstytutsiine pravo Ukrainy [Constitutional Law of Ukraine]. Kyiv: Pravova yednist [in Ukrainian].

7. Zorin, V.A. (1977). Osnovy diplomaticheskoy sluzhby [Fundamentals of the diplomatic service]. Moscow: Mezhd. Otnosheniya [in Russian].

8. Postanova Kabinetu Ministriv Ukrainy "Pro zatverdzhennia Polozhennia pro Ministerstvo zakordonnykh sprav Ukrainy” : vid 30 bereznia 2016 r., № 281 [Resolution of the Cabinet of Ministers of Ukraine "On approval of the Regulation on the Ministry of Foreign Affairs of Ukraine" from March 30, 2016, № 281]. zakon.rada.gov.ua. Retrieved from https://zakon.rada.gov.ua/laws/show/281-2016$\%$ D0\%BF [in Ukrainian].

9. Braillard, Ph. (1994). Relations internationales: une nouvelle discipline. Le trimestre du monde, 3, 29 [in English].

10.Baimuratov, M.O. (2014). Teoretychni aspekty konstytutsiino-pravovoho zabezpechennia zovnishnopolitychnoi diialnosti derzhavy $\mathrm{v}$ umovakh hlobalizatsii ta yevropeiskoi intehratsii [Theoretical aspects of constitutional and legal support of the foreign policy activity of the state in the conditions of globalization and European integration]. Visnyk Mariupolskoho derzhavnoho universytetu. Seriia: Pravo - Bulletin of Mariupol State University. Series: Law, 7, 10-27 [in Ukrainian].

11.Pavlov, E.Ya. (2012). Konstitutsionno-pravovoy mekhanizm osushchestvleniya vneshnikh snosheniy RF (teoreticheskie osnovy) [Constitutional legal mechanism for the implementation of external relations of the Russian Federation (theoretical basis)]. Vestnik MGIMO-Universiteta - Bulletin of MGIMO-University, 2, 156-162 [in Russian].

12.Konstytutsiia Ukrainy : vid 28 chervnia 1996 roku [Constitution of Ukraine from June 28, 1996]. zakon.rada.gov.ua. Retrieved from https://zakon.rada.gov.ua/laws/show/254\%D0\%BA/96$\% \mathrm{D} 0 \% \mathrm{~B} 2 \% \mathrm{D} 1 \% 80$ [in Ukrainian].

13.Zakon Ukrainy "Pro zasady vnutrishnoi i zovnishnoi polityky Ukrainy" : vid 1 lypnia 2010 roku, № 2411-VI [Law of Ukraine "On the principles of domestic and foreign policy of Ukraine" from July 1 , $2010 \quad$ No. 2411-VI]. zakon.rada.gov.ua. $\quad$ Retrieved from https://zakon.rada.gov.ua/laws/show/2411-17 [in Ukrainian].

14.Zakon Ukrainy "Pro dyplomatychnu sluzhbu" : vid 7 chervnia 2018 roku, № 2449-VIII [Law of Ukraine "On Diplomatic Service" from June 7, 2018, № 2449-VIII]. zakon.rada.gov.ua. Retrieved from https://zakon.rada.gov.ua/laws/show/2449-19 [in Ukrainian].

15.Rishennia Rady Natsionalnoi Bezpeky i Oborony Ukrainy "Pro Stratehiiu natsionalnoi bezpeky Ukrainy" : vid 6 travnia 2015 roku [Decision of the National Security and Defense Council "On the National Security Strategy of Ukraine" from 6 May 2015]. zakon.rada.gov.ua. Retrieved from https://zakon.rada.gov.ua/laws/show/n0008525-15 [in Ukrainian].

16.Rosenau, J. (1990). Turbulence in World Politics. Princeton, NJ: Princeton University Press [in English].

17.Kegley, C.W.Jr., Wittkopf, E.R. (2001). American Foreign Policy: Pattern and Process. (5th Ed.). New York: St. Martins Press [in English].

18.Dregner, D.W. (2000). Ideas, Bureaucratic Politics and the Crafting of Foreign Policy. American Journal of Political Science, 44(4), 733-749 [in English].

19.Zelikow, Ph. (1994). Foreign Policy Engineering: From Theory to Practice and Back Again. International Security, 18(4), 143-171 [in English]. 